\title{
Relationship between the regional tectonic activity and crustal structure in the eastern Tibetan plateau discovered by gravity anomaly
}

\author{
Xiao Xu $\cdot$ Rui Gao $\cdot$ Xiaoyu Guo
}

Received: 9 October 2015/Accepted: 7 January 2016/Published online: 20 February 2016

(C) The Author(s) 2016. This article is published with open access at Springerlink.com

\begin{abstract}
The eastern Tibetan plateau has been getting more and more attention because it combines active faults, uplifting, and large earthquakes together in a high-population region. Based on the previous researches, the most of Cenozoic tectonic activities were related to the regional structure of the local blocks within the crustal scale. Thus, a better understanding of the crustal structure of the regional tectonic blocks is an important topic for further study. In this paper, we combined the simple Bouguer gravity anomaly with the Moho depths from previous studies to investigate the crustal structure in this area. To highlight the crustal structures, the gravity anomaly caused by the Moho relief has been reduced by forward modeling calculations. A total horizontal derivative (THD) had been applied on the gravity residuals. The results indicated that the crustal gravity residual is compatible with the topography and the geological settings of the regional blocks, including the Sichuan basin, the Chuxiong basin, the Xiaojiang fault, and the Jinhe fault, as well as the Longmenshan fault zone. The THD emphasized the west margin of Yangtze block, i.e., the Longriba fault zone and the Xiaojiang fault cut through the Yangtze block. The checkboard pattern of the gravity residual in the SongpanGarze fold belt and Chuandian fragment shows that the crust is undergoing a southward and SE-directed extrusion, which is coincident with the flowing direction indicated
\end{abstract}

X. Xu $(\bowtie) \cdot$ R. Gao $\cdot$ X. Guo

Key Laboratory of Earthprobe and Geodynamics, MLR, Institute of Geology, Chinese Academy of Geological Sciences, Beijing, China

e-mail: xxu0712@126.com

X. Xu

Sinoprobe Center, Chinese Academy of Geological Sciences, Beijing, China from the GPS measurements. By integrating the interpretations, the stepwise extensional mechanism of the eastern Tibetan plateau is supported by the southeastward crustal deformation, and the extrusion of Chuandian fragment is achieved by Xianshuihe fault.

Keywords Eastern Tibetan plateau - Tectonic activity · Crustal structures · Gravity anomaly

\section{Introduction}

The eastern Tibetan plateau has been divided into three subunits by four major left-lateral strike-slip faults, including the red river fault, the Xianshuihe fault, the Kunlun fault, and the Haiyuan fault (Fig. 1b). Based on the observed Global Positioning System (GPS) measurements, the Tibetan plateau is dominated by lateral movement (Gan et al. 2007). These four dominant left-lateral strike-slip fault systems control the directions of extrusion from southeast to northeast (Fig. 1a) (Wang et al. 2014; Tapponnier et al. 1986, 2001). With the exception of the Zoige basin, the average elevations of the Songpan-Garze fold belt and Chuandian fragment are both above $4 \mathrm{~km}$. In the northeastern Kunlun fault and the southeastern Chuandian fragment, the elevation decreases smoothly toward the northeast and southeast. The Longmenshan fault belt stands out from the Sichuan basin and eastern Tibet because of its high topographic gradient (Clark and Royden 2000). The recent 40-year earthquakes were located along the major faults at depths of $40 \mathrm{~km}$ and a shallower depth dominantly between 20 and $30 \mathrm{~km}$ (Fig. 1b). Based on the focal mechanism, the Sichuan basin is under compression from eastern Tibet, and the inner part of the Chuandian fragment extends in a southeast direction (Wang et al. 2014). The general 


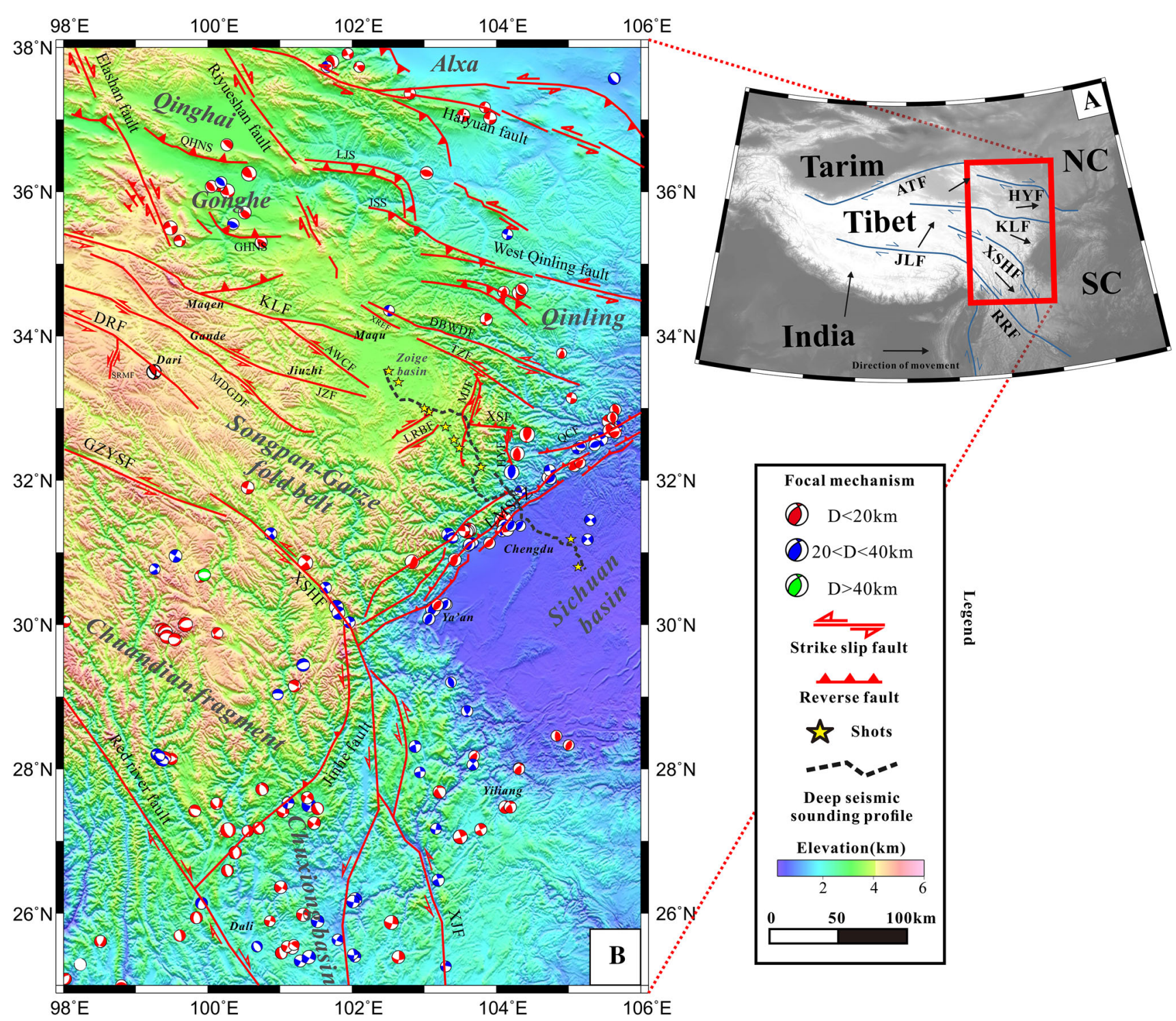

Fig. 1 a Regional topographic map (SRTM, 90 m resolution DEM) of the Tibetan plateau. Red square shows the location of (b); NC North China block, SC South China block, $H Y F$ Haiyuan fault, KLF Kunlun fault, XSHF Xianshuihe fault zone, JLF Jiali fault, $R R F$ Red river fault. b Map of the eastern Tibetan plateau showing the focal mechanism of earthquakes for the past 40 years (earthquake data from www.globalcmt. org). Red lines are the locations of faults. QHNS Qinghainanshan fault, GHNS Gonghenanshan fault, LJS Lajishan fault, JSS Jishishan fault, KLF Kunlun fault, $D B W D F$ Diebu-Bailongjiang fault, XREF Xiarier fault, TZF Tazang fault, $A W C F$ Awancang fault, $L R B F$ Longriba fault zone, $X S F$ Xueshan fault, $M J F$ Minjiang fault, $H Y F$ Haiyuan fault, $Q C F$ Qinchuan fault, $L M S F Z$ Longmenshan fault zone, GZYSF Garze-Yunshu fault, XSHF Xianshuihe fault, XJF Xiaojiang fault (Modified from Tapponnier et al. 2001; He and Chéry 2008; Yuan et al. 2013; Ren et al. 2013; Guo et al. 2015)

consensus is that the 2008 Wenchuan earthquakes resulted from the convergence between the eastern Tibetan plateau and the Sichuan basin divided by the Longmenshan fault zone (Burchfiel et al. 2008; Hubbard and Shaw 2009; Wang et al. 2011). The lower velocity layer, which appears as a featured character in the crust, has been discovered by different types of seismic data (e.g., Liu et al. 2014; Zhang et al. 2011; Yang et al. 2012; Li et al. 2014; Bao et al. 2015). The research of Xu et al. (2015) shows the lower velocity zone contributes to the regional uplifting, earthquakes, and crustal thickening. However, the distribution of lower velocity layer actually appears with discrete and uneven thickness. In addition, none of the proposed models can explain all of the geological and geophysical observations in this area, and the section of lithosphere that was involved in the local tectonic activity has not been identified (Tapponnier et al. 2001; Hubbard and Shaw 2009; Wang et al. 2011; Royden et al. 1997, 2008). In this paper, we view the crust as 
a whole and focused on the regional crustal feature in a map view to determine the lateral contact relationship between crustal structure and tectonic activity.

\section{Geological settings}

The Chuandian fragment is next to the Songpan-Garze fold belt and Sichuan basin and is bounded to the northeast by the Xianshuihe-Xiaojiang fault (Wang et al. 1998). As part of the rigid and stable Yangtze Craton, the Sichuan basin was cut through by the Xianshuihe-Xiaojiang fault during the late Cenozoic (Roger et al. 1995). The extrusion and clockwise rotation of the Chuandian fragment are supported by paleomagnetic measurements, GPS measurements, and the focal mechanisms of the earthquakes (Chen et al. 1995; Molnar and Lyon-Caen 1988; Holt et al. 1991). The Chuxiong basin is similar to the Sichuan basin in that both possess characteristics of the Yangtze craton, which contains Early Proterozoic crystalline basement (Fig. 1b) (Wang et al. 1998). The Songpan-Garze fold belt is located in the eastern part of the Tibetan plateau and is separated from west of the Sichuan basin by the Longmenshan fault zone (Fig. 1b) (Burchfield et al. 1995). The Songpan-Garze terrane is filled with thick Triassic flyschoid rocks due to the closure of Paleo-thethys Ocean during the Early Jurassic (Roger et al. 2010).

The Red river fault zone is the major geological boundary between the Indo-china block and the South China Platform (Fig. 1a) (Mazur et al. 2012). The Red river fault zone has two phases of strike-slip deformation (Tapponnier et al. 1986; Leloup et al. 2001). The earlyphase tectonic activity along the Red river fault zone was left-lateral motion between the latest Eocene and early Miocene (Tapponnier et al. 1986; Leloup et al. 2001; Lacassin et al. 1997; Morley 2002). The latest phase changed to right-lateral slipping at $5 \mathrm{Ma}$ with approximately $25 \mathrm{~km}$ of displacement (Tappinnier and Molnar 1977; Allen et al. 1984; Replumaz et al. 2001; Leloup et al. 1993).

The Xianshuihe-Xiaojiang fault zone is one of the most active NW-trending fault zones within the southeastern margin of the Tibetan plateau (Fig. 1a) (Wang et al. 1998). It caused several large earthquakes with left-lateral motion and magnitudes exceeding $M_{\mathrm{S}} 7.0$ because of the intracontinental deformation during the Cenozoic (Deng et al. 2007; Guo et al. 2012; Molnar and Tapponnier 1978; Avouac and Tapponnier 1993). The fault zone has up to $100 \mathrm{~km}$ of total displacement with four branches and extends for more than $1400 \mathrm{~km}$ (Burchfield et al. 1995; Wang et al. 1998; Wang et al. 2009). The XianshuiheXiaojiang fault zone can be divided into two phases: an early stage from 13 to $5 \mathrm{Ma}$ and a late stage from $5 \mathrm{Ma}$ until present. The Xiaojiang fault was initialed from the continuous clockwise rotation of the eastern Indo-China syntaxis (Wang et al. 2009).

The Kunlun fault is one of the major structures in the active deformation history of the Tibetan plateau (Avouac and Tapponnier 1993). The fault also acts as the northern boundary of the Songpan-Garze terrane along the Anyemaqen suture (Yin and Harrison 2000) and connects with the Mianlue suture in east (Meng et al. 2005). It extends nearly $1500 \mathrm{~km}$ (Fig. 1) and acts as a transition from flat, high-elevation plateau to mountain-basin alternate terrain (Kirby et al. 2007). Along the southern margin of the Qaidam basin, the Kunlun Mountain uplifted between $~ 35$ and $\sim 20-15 \mathrm{Ma}$ (Fig. 1b) due to crustal shortening that occurred during that time along with the acceleration of exhumation near $15 \mathrm{Ma}$ (Yuan et al. 2013; Lu et al. 2012). The initial left-lateral slip of the Kunlun fault zone began at $\sim 20-15$ to $\sim 8 \mathrm{Ma}$ on the $\mathrm{E}-\mathrm{W}$ strike in the western part of the fault system (Jolivet et al. 2003). The total displacement is difficult to estimate because of the discontinuities of the fault; however, the deflection of the Yellow river in the eastern part of the fault indicates that the displacement is more than $85 \mathrm{~km}$ (Gaudemer et al. 1989; Van der Woerd et al. 2002). Kirby et al. (2007) calculated the slip rates along the eastern $150 \mathrm{~km}$ of the Kunlun fault based on the displaced fluvial terrace risers and ${ }^{14} \mathrm{C}$ ages of the terrace material; the slip rates decrease from $>10$ to $<2 \mathrm{~mm} /$ year. Additionally, they speculated that the shortening across northeastern Tibet resulted in the rotation of the eastern part of the Kunlun fault. In the present study, we build an evolution model to explain how the crustal deformation of northern Tibet caused the rotation of the eastern part of the Kunlun fault between Maqen and Maqu (Fig. 1b).

The $1000 \mathrm{~km}$-long left-lateral east-striking Haiyuan fault system extends from the central Qianlianshan in the west to the Liupanshan to the east (Fig. 1b). This fault system accommodates the deformation caused by the India-Eurasia collision (Jolivet et al. 2012). The Haiyuan fault system triggered two $M_{\mathrm{W}} 8$ earthquakes, the Haiyuan earthquake in 1920 and the Gulang earthquake in 1927 (e.g., Deng et al. 1986; Xu et al. 2010). The Haiyuan earthquake in the eastern section of the Haiyuan fault was caused by strike-slip movement with a rupture of $220 \mathrm{~km}$. In the western end of the Haiyuan fault, the Gulang earthquake was triggered by south-dipping thrusting. Previous studies on the focal mechanism show that the Haiyuan fault mainly dips southwest and is thrusting at the connection of the southeastern end of the Qilianshan. It then transforms into a sinistral strike-slip faulting eastward (Fig. 3a). The Holocene slip rate of the Haiyuan fault is $19 \pm 5 \mathrm{~mm} /$ year in west (Lasserre et al. 2002) and $4.5 \pm 1 \mathrm{~mm} /$ year on average ( $\mathrm{Li}$ et al. 2009). 
The Longmenshan fault zone was reactivated during the Cenozoic, which contributed significantly to the uplift of the Tibetan plateau. According to GPS measurements, no significant active convergence $(<4 \mathrm{~mm} / \mathrm{year})$ of the Longmenshan belt was recorded relative to the Sichuan basin (Zhang 2013). However, the 2008 Wenchuan earthquake occurred due to the significant accumulation of stress along the Longmenshan fault zone. Results from fission track dating documented the reactivation of the Wenchuan and Beichuan faults during the Cenozoic (Xu et al. 2008). Additionally, the Beichuan fault has been the major active structure of the Longmenshan fault zone since the late Miocene. It was activated during the 2008 Wenchuan earthquake and possesses an average uplift rate between 0.7 and $1.2 \mathrm{~mm} /$ year, with an estimated initiation age between 5 and $12 \mathrm{Ma}$ (Burchfiel et al. 2008). At a regional scale, Wang et al. (2012) proposed two major rapid exhumation patterns: a slow exhumation during the early Cenozoic and two episodes of rapid exhumation (30-25 and 15-8 Ma). The current exhumation rate is constrained at a value less than $0.5 \mathrm{~mm} /$ year (Wang et al. 2012). The highest density of large earthquakes is concentrated along the Longmenshan fault zone in this area with focal depths ranging from 10 to $30 \mathrm{~km}$ (Xu et al. 2015).

\section{Data and methods}

In this study, we applied the inversion of Bouguer gravity anomaly with previously reported local seismic data to extract the gravity anomaly produced by the crust.

\subsection{Seismic data}

The SinoProbe-02 series of seismic experiments on both refraction and reflection profiles was a recent ambitious effort to investigate the seismic structure of the lithosphere beneath China (Dong et al. 2011). Among the studied profiles, the profiles across the Longmenshan area were a main focus of the experiments due to the need to better understand the tectonics and earthquake hazards in the region. However, the deployment of seismic recorders and sources has proven difficult due to the rugged topography, limited road access, and landslides from the 2008 earthquake. Nonetheless, we successfully completed these seismic profiles, which have been reported in two articles (Guo et al. 2013, 2014). We aimed to determine the regional crustal characteristics of this area and image the structures of the eastern edge of Tibet, the Longmenshan, and the westernmost Sichuan basin. This allowed us to obtain first-hand data on the structural features in the transition zone from the eastern Tibetan plateau [Songpan-
Garze terrane (SGT)] across the western Yangtze Proterozoic block to the Sichuan basin. In addition, we collected a 400-km-long refraction and wide-angle reflection profile (Fig. 1b) during the seismic experiment. In total, we deployed 355 TEXAN seismic recorders at a station spacing of $1.5 \mathrm{~km}$. We initially designed a straightline spread to obtain seismic refraction data. However, this straight-line spread was eventually altered to follow a highway due to the severe topography. Refraction data were obtained from 12 sources ranging in size from 2000 to $500 \mathrm{~kg}$. In the final analysis, only 10 of the 12 sources were used due to the low signal-to-noise ratio of the other two. Figure 2 shows the final velocity model (Xu et al. 2015).

\subsection{Gravity data}

The gravity anomaly data employed in this study were obtained from the International Center for Global Earth Models. These data were collected through the long term archiving of existing global gravity field models, and the resolution is $0.1^{\circ} \times 0.1^{\circ}$ (http://icgem.gfz-potsdam.de/ ICGEM/Service.html), which enables the calculation of gravity functions from the spherical harmonic models on freely selectable grids. Simple Bouguer gravity anomaly values were downloaded and mapped with the Geosoft/ Oasis Montaj processing and analysis package using a Bouguer reduction density of $2.67 \mathrm{~g} / \mathrm{cm}^{3}$. However, the density value for the sediments was determined to be between 2.3 and $2.4 \mathrm{~g} / \mathrm{cm}^{3}$ based on the final seismic velocity from the wide-angle reflection and refraction seismic data and the application of Gardner's rule (Gardner et al. 1974) to estimate density from seismic velocity. As a result, the Bouguer correction was redone using a density of $2.35 \mathrm{~g} / \mathrm{cm}^{3}$. After this reduction, the new simple Bouguer gravity anomalies in the SGT were obtained. These values were about $\sim 30 \mathrm{mGal}$ less negative than the original data. The resolution of the elevation values employed in this calculation was reduced from the Shuttle Radar Topography Mission (SRTM) data, which have a resolution of 3 arc-seconds, because the resolution of the simple Bouguer gravity anomaly is low.

\subsection{Inversion of gravity data}

The regional simple Bouguer anomaly is strongly controlled by the crustal thickness (Fig. 3a). In this study, we aim to identify the characteristics of structures within the crust; thus, the anomaly of Moho depth has been removed. The Moho depth was determined from the results of the receiver function (Fig. 3a) (Xu et al. 2013; Sun et al. 2012).

The integrated 2D gravity modeling was performed during the SinoProbe-02 project ( $\mathrm{Xu}$ et al. 2015). The gravity model (Fig. 3c) shows that the trend of the simple 


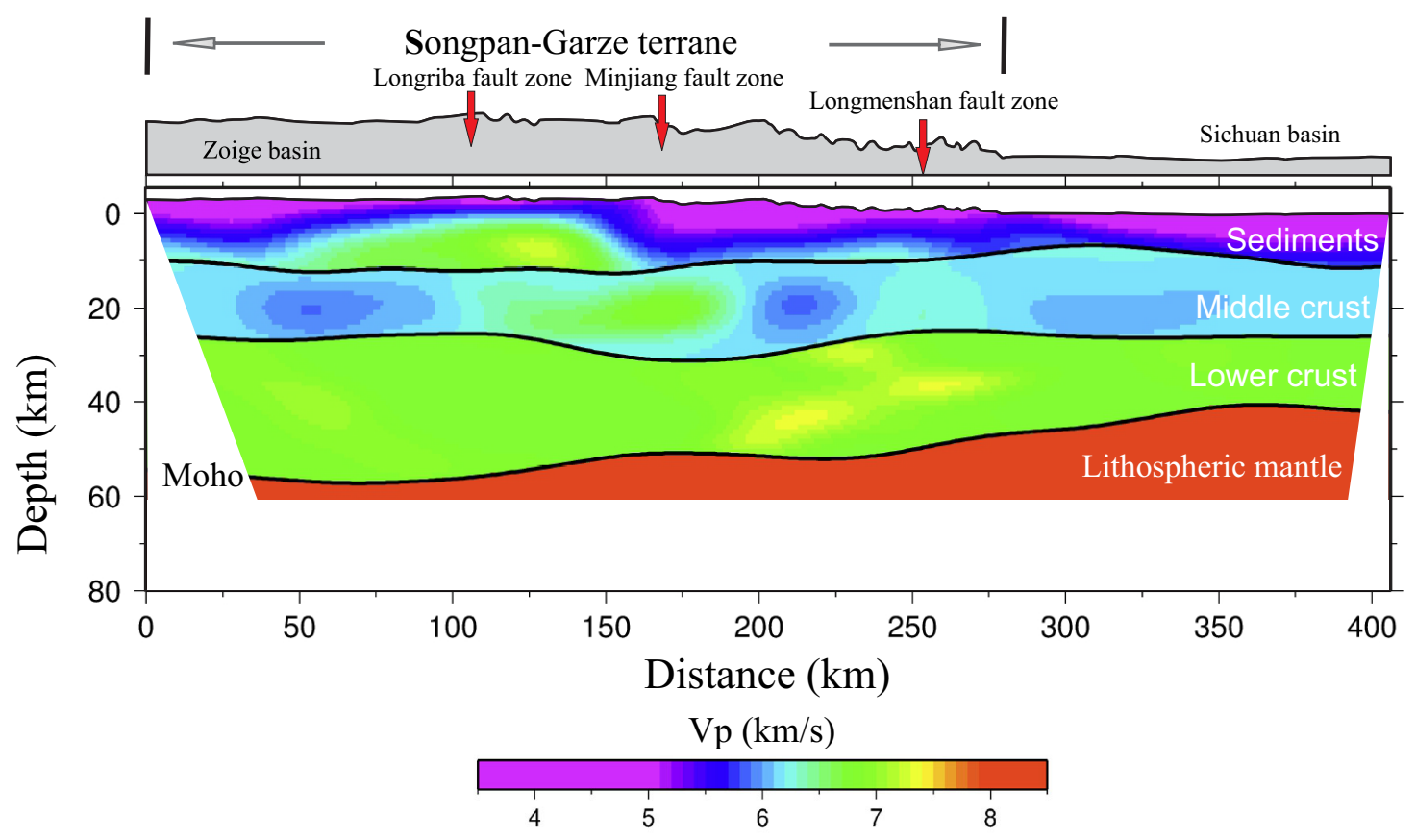

Fig. 2 Final velocity model derived from the combined stacking velocity and travel-time inversion (Xu et al. 2015)

Bouguer anomaly is consistent with that of the Moho depth, indicating that it is strongly controlled by the variations in crustal thickness. After minor density iterations in the upper crust guided by the seismic results, it is clear that the thickness of the Triassic Songpan-Garze flysch increases from east to west, where the greatest depth is about $12 \mathrm{~km}$. Aided by thrusting, the base of the sediments deepens beneath the Longmenshan fault zone (LMSFZ) and shallows toward both the Sichuan basin and the SGT. To fit the gravity data, an upper-crustal higher density lens was inserted under the sediments in the Minjiang fault zone area. Both the middle and lower crusts have variable thicknesses, likely due to the eastward compression against the rigid Sichuan basin in this area. The thickest middle crust appears immediately to the west of the LMSFZ, while the thickest lower crust appears beneath the SGT. Therefore, we suggest that the thickening of the middle crust west of the LMSFZ is caused by the eastward compression, which is blocked by the stable rigid lithosphere of the Sichuan basin.

The gravity forward modeling used an average density of $2.82 \mathrm{~g} / \mathrm{cm}^{3}$, which was calculated from the integrated 2D gravity modeling results (Fig. 3e). The forward modeling results (Fig. 4a) clearly show the same trend with Moho depth. However, the distortions (relatively shallow) in the Songpan-Garze fold belt and the Chuandian fragment (Fig. 3a) are not shown in the forward modeling results (Fig. 4a). Figure $2 b$ shows the results of the simple Bouguer anomaly after the reduction of crustal thickness.
The research area is composed of several blocks, and the boundaries on the surface were identified as faults (Wang et al. 2014; Taylor and Yin 2009). The total horizontal derivative (THD) of the gravity anomaly has been suggested for use as an edge detector (Cooper and Cowan 2006). THD is defined as

$\mathrm{THD}=\operatorname{sqrt}\left[(\partial f / \partial x)^{2}+(\partial f / \partial y)^{2}\right]$,

where $(\partial f / \partial x)$ and $(\partial f / \partial y)$ measure the rate of change of the potential fields in the $X$ and $Y$ directions, respectively.

\section{Results}

In general, the residual of the crustal gravity anomaly (Fig. 4b) has the same relief as the regional topography (Fig. 4d). The Songpan-Garze fold belt has the lowest gravity anomaly (Fig. 4b) because of its huge sediment thickness (Roger et al. 2010; Liu et al. 2013). Most thrust faults fit the trend of the gradient of the gravity anomaly. The Garze-Yunshu fault, Xianshuihe fault, and Kunlun fault are ambiguous on the crustal gravity anomaly (Fig. 4b). The high gravity anomaly in the Chuxiong basin is separated from the Sichuan basin by the XianshuiheXiaojiang fault. This shows that the crustal composition of the Chuxiong basin is similar to that of the Sichuan basin (Wang et al. 2014). The low gravity anomaly in the Songpan-Garze fold belt and Chuandian fragment has a checkerboard-like pattern, which shows that the crust is 

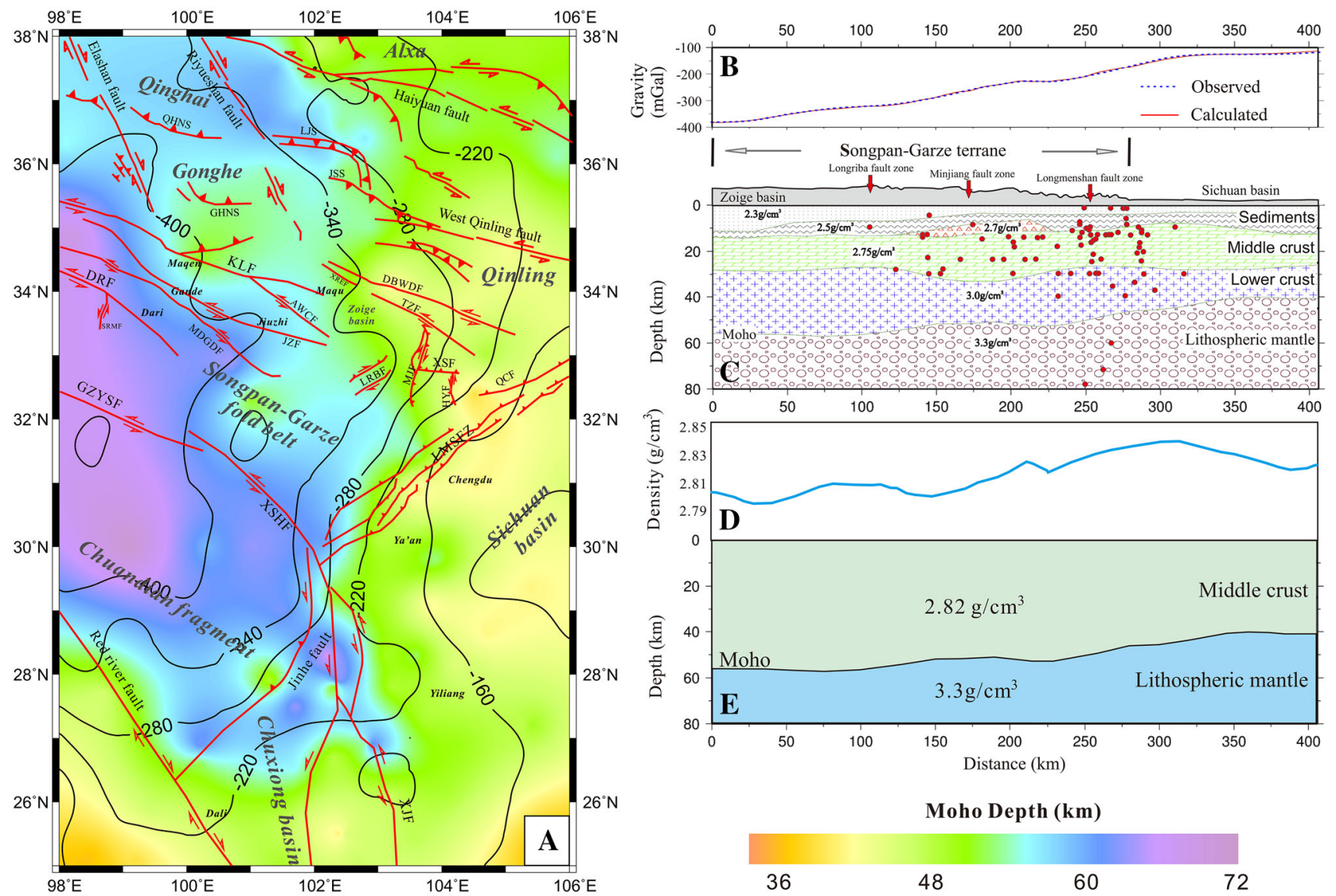

Fig. 3 a Moho depth map with simple Bouguer anomaly contours. b Observed and computed Bouguer anomalies. c Final 2D integrated gravity density model. The red dots indicate the projected hypocenters of the earthquakes (magnitude $>6$ ) that occurred in the past 100 years (earthquake data from the USGS global database). d The Moho depth is unified to be $60 \mathrm{~km}$; refer to Fig. 2c for crustal density. e Density model for forward gravity modeling

undergoing a southward and SE-directed extrusion in the eastern Tibetan plateau. This anomaly shows the same direction as the strain rate field based on GPS velocities (Gan et al. 2007). After the Moho reduction, the gravity anomaly is still in a mirror-shape (Fig. 4b). The average density of the crust increases from the Songpan-Garze fold belt to the Sichuan basin (Fig. 3d); thus, the average density of thicken crust is lower than normal crust.

The THD of the gravity anomaly shows that the western part of the Longmenshan fault zone is a transition zone between the Sichuan basin and the Songpan-Garze fold belt. The Longriba fault zone acts as the western boundary of this transition zone (Fig. 4d) and could represent the western margin of the Yangtze block (Guo et al. 2015). The transition zone continues in the southwestern direction and extends to the northwestern region of the Chuxiong basin. The Lajishan thrust fault and Jishishan thrust fault are outstanding in the northern Tibetan plateau. Within the Songpan-Garze fold belt, the gradient of the gravity anomaly does not embody any strike-slip fault zones.

\section{Discussion}

The residual of the crustal gravity anomaly has two features: (1) it is better correlated with the topography than with the Moho depth and (2) it is more consistent with thrust faults than with strike-slip faults. A previous study (Xu et al. 2015) demonstrated that uplift can occur under continuous convergence along the thrust fault; however, crustal thickening requires a strong and rigid block to act as a backstop. Thus, the crust is thicker in the northwest of the Chuxiong basin and Sichuan basin owing to fact that the Songpan-Garze fold belt is softer than the Yangtze block. The strain accumulates along the thrust fault (Xu et al. 2015), producing faulting, thickening, and uplift in the soft block.

Based on the analysis, we propose an evolution model in this area (Fig. 5). The model is generally proposed according to the lateral extrusion model (Tapponnier et al. 2001). The Red river fault acts as a left-lateral strike-slip fault between 35 and $15 \mathrm{Ma}$. However, after $15 \mathrm{Ma}$, the 

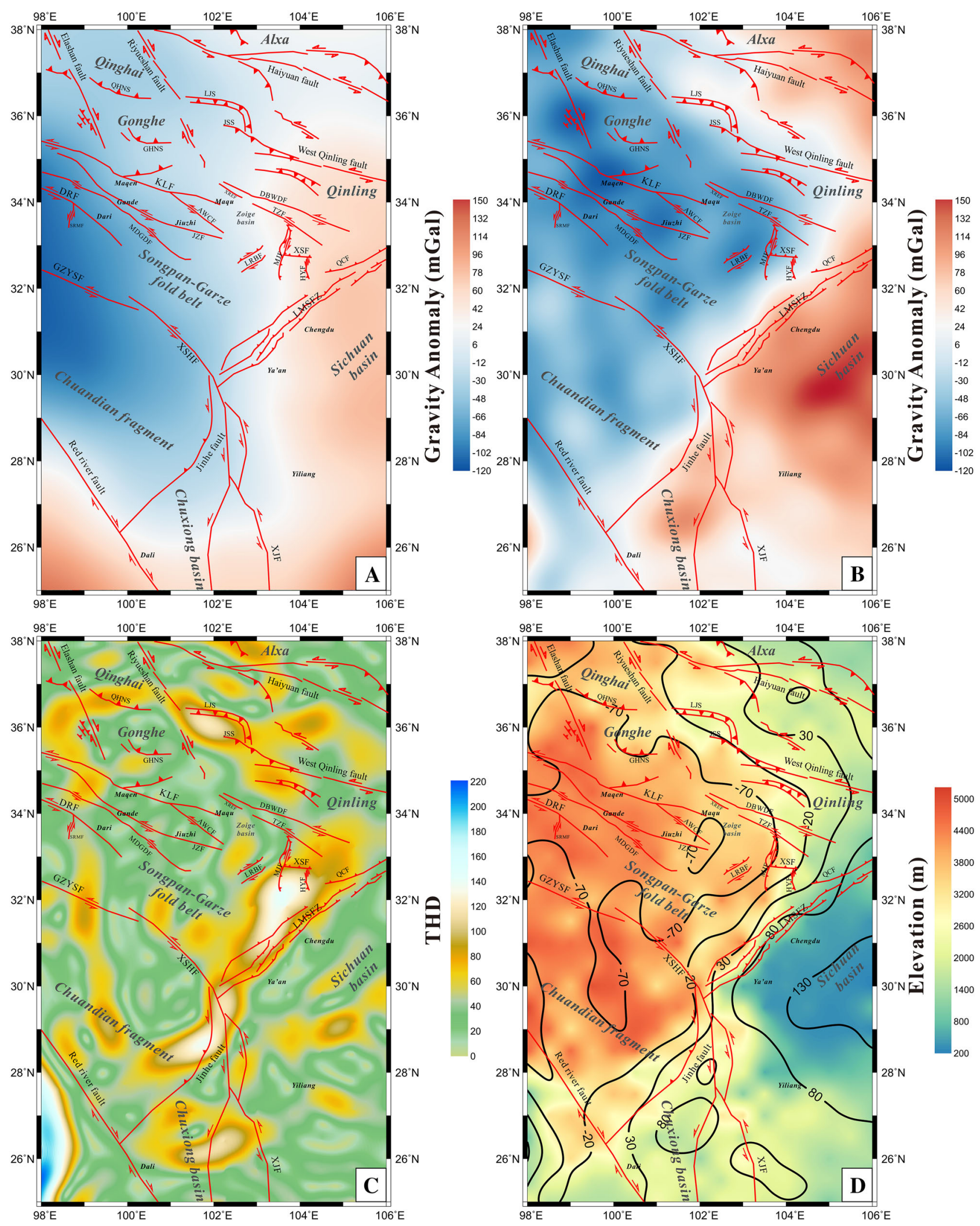

Fig. 4 a Bouguer anomaly computed using the density model in Fig. 2e. b The crustal gravity residual. c The total horizontal derivative (THD) of the crustal gravity residual. d The topography map with the crustal gravity residual contours 


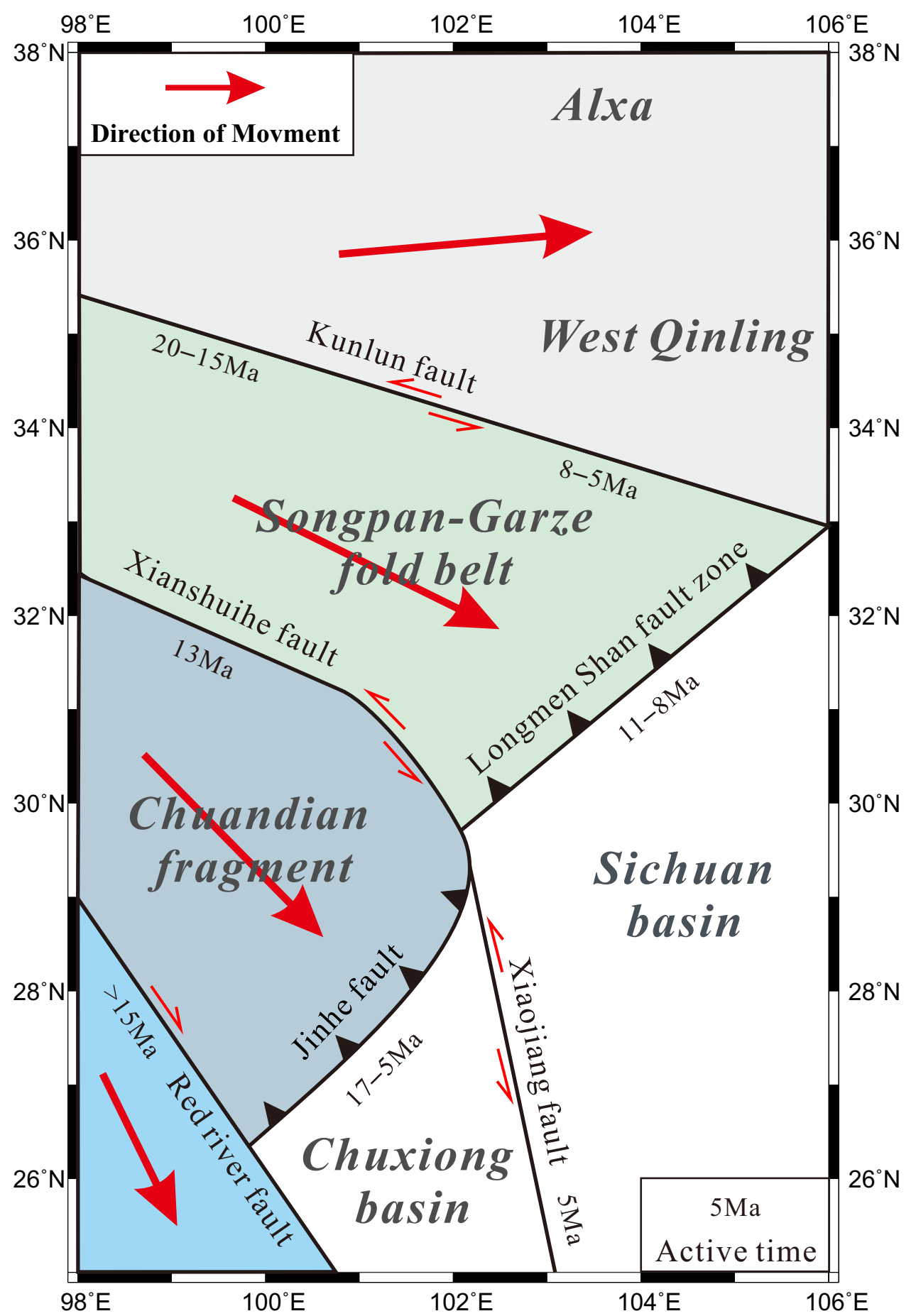

Fig. 5 Simple cartoon showing the stepwise extrusion model in the eastern Tibetan Plateau

Red river fault switched to a dextral strike-slip fault (Lacassin et al. 1997; Tapponnier et al. 2001), and the Songpan-Garze fold belt became shortened and thickened. On the other hand, the Longmenshan fault zone and the Jinhe fault zone were the eastern boundary of the Tibetan plateau before $17 \mathrm{Ma}$ (Wang et al. 2009). After $17 \mathrm{Ma}$, the
Songpan-Garze fold belt began to be cut by the Xianshuihe fault zone. The Jinhe fault was active between 17 and $5 \mathrm{Ma}$, and, according to a previous study, the Jinhe fault was a transpressional structure at the southern end of the Xianshuihe fault zone during this time (Wang et al. 2012). The crustal extrusion resulted in the thrusting of the 
Songpan-Garze fold belt toward the Sichuan basin along the Longmenshan fault zone. A major phase of exhumation of the Longmenshan fault zone started at 8-11 Ma (Godard et al. 2009). The Kunlun fault zone is the northern boundary of Songpan-Garze fold belt, and the initiation age becomes younger toward the east (Yuan et al. 2013).

\section{Conclusions}

Based on our research, the crustal gravity residual is compatible with the topography and distribution of regional tectonic units, including the Sichuan basin, Chuxiong basin, Xiaojiang fault, Jinhe fault, Longmenshan fault zone, Longriba fault zone, and the thrust faults in the northern Tibetan plateau. Combined with previous research suggesting that the Songpan-Garze fold belt is easily deformed against a rigid block (like the Yangtze block), high elevation and thick crust were built up accordingly as a result. The Longriba fault zone could be the western boundary of the Yangtze block, and the Songpan-Garze flysch overlays the western Yangtze block between the Longmenshan fault zone and the Longriba fault zone. The inner crustal north-south-directed extension in the Chuandian fragment can be identified by the focal mechanism and crustal gravity residual. The Xiaojiang fault cut through the Yangtze block. With the exception of the Xiaojiang fault, few strike-slip faults are correlated with the crustal gravity residual. Together, these interpretations indicate that the stepwise extensional mechanism of the eastern Tibetan plateau is supported by the crustal scale deformation.

Acknowledgments We would like to acknowledge the anonymous reviewers for their valuable comments on earlier versions of this manuscript. This work was supported by the National Natural Science Foundation of China (Grant Nos. 41430213 and 41304064).

Open Access This article is distributed under the terms of the Creative Commons Attribution 4.0 International License (http://crea tivecommons.org/licenses/by/4.0/), which permits unrestricted use, distribution, and reproduction in any medium, provided you give appropriate credit to the original author(s) and the source, provide a link to the Creative Commons license, and indicate if changes were made.

\section{References}

Allen CR, Gillespie AR, Han Y, Sieh KE, Zhang B, Zhu C (1984) Red River and associated faults, Yunnan Province, China: quaternary geology, slip rates and seismic hazard. Geol Soc Am Bull 95(6):686-700. doi:10.1130/0016-7606(1984)95<686: RRAAFY $>2.0 . \mathrm{CO} ; 2$

Avouac JP, Tapponnier P (1993) Kinematic model of active deformation in central Asia. Geophys Res Lett 20(10):895-898

Bao X, Sun X, Xu M, Eaton DW, Song X, Wang L, Ding Z, Mi N, Li H, Yu D, Huang Z, Wang P (2015) Two crustal low-velocity channels beneath SE Tibet revealed by joint inversion of Rayleigh wave dispersion and receiver functions. Earth Planet Sci Lett 415:16-24

Burchfiel BC, Royden LH, Van der Hilst R, Hager B, Chen Z-L, King R, Li C, Lü J, Yao H, Kirby E (2008) A geological and geophysical context for the Wenchuan earthquake of 12 May 2008, Sichuan, People's Republic of China. GSA Today 18(7):5

Burchfield BC, Chen Z, Liu Y, Royden LH (1995) Tectonics of the Longmen Shan and adjacent regions, Central China. Int Geol Rev 37:661-735

Chen H-H, Dobson J, Heller F, Hao J (1995) Paleomagnetic evidence for clockwise rotation of the Simao region since the Cretaceous: a consequence of India-Asia collision. Earth Planet Sci Lett 134(1):203-217

Clark MK, Royden LH (2000) Topographic ooze: building the eastern margin of Tibet by lower crustal flow. Geology 28(8):703-706

Cooper GRJ, Cowan DR (2006) Enhancing potential field data using filters based on the local phase. Comput Geosci 32(10):1585-1591

Deng Q, Chen S, Song F, Zhu S, Wang Y (1986) Variations in the geometry and amount of slip on the Haiyuan (Nanxihaushan) fault zone, China and the surface rupture of the 1920 Haiyuan earthquake. Earthq Source Mech Geophys Monogr 37:169-182

Deng Q-D, et al (2007) Active tectonics map of China. Earthquake Press, Beijing

Dong S, Li T, Gao R, Hou H, Li Y, Zhang S, Keller GR and Liu M (2011) A multidisciplinary earth science research program in China. Eos, Trans Am Geophys Union 92(38):313-314.

Gan W, Zhang P, Shen Z-K, Niu Z, Wang M, Wan Y, Zhou D, Cheng J (2007) Present-day crustal motion within the Tibetan Plateau inferred from GPS measurements. J Geophys Res 112(B8):B08416

Gardner GHF, Gardner LW, Gregory AR (1974) Formation velocity and density - the diagnostic basics for stratigraphic traps. Geophysics 39:770-780. doi:10.1190/1.1440465

Gaudemer Y, Tapponnier P, Turcotte DL (1989) River offsets across active strike-slip faults. Ann Tecton 3(2):55-76

Godard V, Pik R, Lavé J, Cattin R, Tibari B, de Sigoyer J, Pubellier M, Zhu J (2009) Late Cenozoic evolution of the central Longmen Shan, eastern Tibet: insight from (U-Th)/He thermochronometry. Tectonics 28:TC5009. doi:10.1029/2008TC002407

Guo J-M, Zheng J-J, Guan B-B, Fu B-H, Shi P-L, Du J-G, Xie C, Liu L (2012) Coseismic surface rupture structures associated with $2010 M_{\mathrm{S}} 7.1$ Yushu Earthquake, China. Seismol Res Lett 83(1):109-118

Guo XY, Gao R, Keller GR, Xu X, Wang HY, Li WH (2013) Imaging the crustal structure beneath the eastern Tibetan Plateau and implications for the uplift of the Longmen Shan range. Earth Planet Sci Lett 379:72-80. doi:10.1016/j.epsl.2013.08.005

Guo XY, Keller GR, Gao R, Xu X, Wang HY, Li WH (2014) Irregular western margin of the Yangtze block as a cause of variation in tectonic activity along the Longmen Shan fault zone, eastern Tibet. Int Geol Rev 56:473-480. doi:10.1080/00206814. 2013.873358

Guo X, Gao R, Xu X, Keller GR, Yin A, Xiong X (2015) Longriba fault zone in eastern Tibet: an important tectonic boundary marking the westernmost edge of the Yangtze block. Tectonics 34:970-985. doi:10.1002/2015TC003880

He J, Chéry J (2008) Slip rates of the Altyn Tagh, Kunlun and Karakorum faults (Tibet) from 3D mechanical modeling. Earth Planet Sci Lett 274(1):50-58

Holt WE, Ni JF, Wallace TC, Haines A (1991) The active tectonics of the eastern Himalayan syntaxis and surrounding regions. J Geophys Res 96(B9):14595-14632

Hubbard J, Shaw JH (2009) Uplift of the Longmen Shan and Tibetan Plateau, and the 2008 Wenchuan $(M=7.9)$ earthquake. Nature 458(7235):194-197 
Jolivet M, Brunel M, Seward D, Xu Z, Yang J, Malavieille J, Roger F, Leyreloup A, Arnaud N, Wu C (2003) Neogene extension and volcanism in the Kunlun Fault Zone, northern Tibet: new constraints on the age of the Kunlun Fault. Tectonics 22(5):1052

Jolivet R, Lasserre C, Doin MP, Guillaso S, Peltzer G, Dailu R, Sun J, Shen Z-K, Xu X (2012) Shallow creep on the Haiyuan fault (Gansu, China) revealed by SAR interferometry. J Geophys Res Solid Earth 117(B6):B06401

Kirby E, Harkins N, Wang E, Shi X, Fan C, Burbank D (2007) Slip rate gradients along the eastern Kunlun fault. Tectonics 26(2):TC210

Lacassin R, Maluski H, Leloup H, Tapponnier P, Hinthong C, Siribhakdi K, Chuaviroj S, Charoenravat A (1997) Tertiary diachronic extrusion and deformation of western Indochina: structural and 40Ar/39Ar evidence from NW Thailand. J Geophys Res 102(B5):10013-10037

Lasserre C, Gaudemer Y, Tapponnier P, Mériaux AS, Van der Woerd J, Yuan D, Ryerson F, Finkel R, Caffee MW (2002) Fast late Pleistocene slip rate on the Leng Long Ling segment of the Haiyuan fault, Qinghai, China. J Geophys Res Solid Earth 107(B11):ETG-4

Leloup PH, Harrison TM, Ryerson FJ, Chen W, Qi L, Tapponnier P, Lacassin R (1993) Structural, petrological and thermal evolution of a Tertiary ductile strike-slip shear zone, Diancang Shan, Yunnan. J Geophys Res 98(B4):6715-6743. doi:10.1029/92JB02791

Leloup PH, Arnaud N, Lacassin R, Kienast JR, Harrison TM, Phan Trong TT, Replumaz A, Tapponnier P (2001) New constraints on the structure, thermochronology, and timing of the Ailao Shan-Red River shear zone, SE Asia. J Geophys Res 106(B4):6683-6732

Li C, Zhang PZ, Yin J, Min W (2009) Late quaternary left-lateral slip rate of the Haiyuan fault, northeastern margin of the Tibetan Plateau. Tectonics 28(5):TC5010. doi:10.1029/2008TC002302

Li H, Shen Y, Huang Z, Li X, Gong M, Shi D, Sandvol E, Li A (2014) The distribution of the mid-to-lower crustal low-velocity zone beneath the northeastern Tibetan Plateau revealed from ambient noise tomography. J Geophys Res Solid Earth 119(3):1954-1970

Liu S, Deng B, Jansa L, Wang G, Li X, Wang C, Liu S, Li Z, Li J, Sun W, Ran B (2013) Late Triassic thickening of the Songpan-Garze Triassic flysch at the edge of the northeastern Tibetan Plateau. Int Geol Rev 55(16):2008-2015

Liu QY, van der Hilst RD, Li Y, Yao HJ, Chen JH, Guo B, Qi SH, Wang J, Huang H, Li SC (2014) Eastward expansion of the Tibetan Plateau by crustal flow and strain partitioning across faults. Nat Geosci 7(5):361-365

Lu H, Wang E, Shi X, Meng K (2012) Cenozoic tectonic evolution of the Elashan range and its surroundings, northern Tibetan Plateau as constrained by paleomagnetism and apatite fission track analyses. Tectonophysics 580:150-161

Mazur S, Green C, Stewart MG, Whittaker JM, Williams S, Bouatmani R (2012) Displacement along the Red River Fault constrained by extension estimates and plate reconstructions. Tectonics 31(5):TC5008

Meng QR, Wang E, Hu JM (2005) Mesozoic sedimentary evolution of the northwest Sichuan basin: implication for continued clockwise rotation of the South China block. Geol Soc Am Bull 117(3-4):396-410

Molnar P, Lyon-Caen H (1988) Some simple physical aspects of the support, structure, and evolution of mountain belts. Geol Soc Am Spec Pap 218:179-208

Molnar P, Tapponnier P (1978) Active tectonics of Tibet. J Geophys Res 83:5361-5375

Morley CK (2002) A tectonic model for Tertiary evolution of strikeslip faults and rift basins in SE Asia. Tectonophysics 347(4):189-215

Ren J, Xu X, Yeats RS, Zhang S (2013) Millennial slip rates of the Tazang fault, the eastern termination of Kunlun fault: implications for strain partitioning in eastern Tibet. Tectonophysics 608:1180-1200

Replumaz A, Lacassin R, Tapponnier P, Leloup PH (2001) Large river offsets and Plio-Quaternary dextral slip rate on the Red River fault (Yunnan, China). J Geophys Res 106(B1):819-836. doi:10.1029/2000JB900135

Roger F, Calassou S, Lancelot J, Malavieille J, Mattauer M, Xu Z-Q, Hao Z-W, Hou L-W (1995) Miocene emplacement and deformation of the Konga Shan granite (Xianshui He fault zone, west Sichuan, China): geodynamic implications. Earth Planet Sci Lett 130(1-4):201-216

Roger F, Jolivet M, Malavieille J (2010) The tectonic evolution of the Songpan-Garze (North Tibet) and adjacent areas from Proterozoic to present: a synthesis. J Asian Earth Sci 39(4):254-269

Royden LH, Burchfiel BC, King RW, Wang E, Chen Z, Shen F, Liu Y (1997) Surface deformation and lower crustal flow in eastern Tibet. Science 276(5313):788-790

Royden LH, Burchfiel BC, van der Hilst RD (2008) The geological evolution of the Tibetan Plateau. Science 321(5892):1054-1058

Sun Y, Niu F, Liu H, Chen Y, Liu J (2012) Crustal structure and deformation of the SE Tibetan Plateau revealed by receiver function data. Earth Planet Sci Lett 349:186-197

Tappinnier P, Molnar P (1977) Active faulting and tectonics in China. J Geophys Res 82(20):2905-2930. doi:10.1029/JB082i020p02905

Tapponnier P, Peltzer G, Armijo R (1986) On the mechanics of the collision between India and Asia. Geol Soc Lond Spec Publ 19(1):113-157

Tapponnier P, Xu Z-Q, Roger F, Meyer B, Arnaud N, Wittlinger G, Yang J-S (2001) Oblique stepwise rise and growth of the Tibet Plateau. Science 294(5547):1671-1677

Taylor M, Yin A (2009) Active structures of the Himalayan-Tibetan orogen and their relationships to earthquake distribution, contemporary strain field, and Cenozoic volcanism. Geosphere 5(3): 199-214

Van Der Woerd J, Tapponnier P, Ryerson FJ, Meriaux AS, Meyer B, Gaudemer Y, Finkel RC, Caffee MW, Zhao G, Xu Z (2002) Uniform postglacial slip-rate along the central $600 \mathrm{~km}$ of the Kunlun Fault (Tibet), from 26Al, 10Be, and 14C dating of riser offsets, and climatic origin of the regional morphology. Geophys J Int 148(3):356-388

Wang E, Burchfiel BC, Royden LH, Chen L-Z, Chen J-S, Li W-X, Chen Z-L (1998) Late Cenozoic Xianshuihe-Xiaojiang, Red River, and Dali Fault Systems of Southwestern Sichuan and Central Yunnan, China. Geol Soc Am Spec Pap 327:1-108

Wang S, Fang X, Zheng D, Wang E (2009) Initiation of slip along the Xianshuihe fault zone, eastern Tibet, constrained by $\mathrm{K} / \mathrm{Ar}$ and fission-track ages. Int Geol Rev 51(12):1121-1131. doi:10.1080/ 00206810902945132

Wang Q, Qiao X-J, Lan Q-G, Jeffrey F, Yang S-M, Xu C-J, Yang Y-L, You X-Z, Tan K, Chen G (2011) Rupture of deep faults in the 2008 Wenchuan earthquake and uplift of the Longmen Shan. Nat Geosci 4(9):634-640

Wang E, Kirby E, Furlong KP, Van Soest M, Xu GQ, Shi X, Kamp PJ, Hodges KV (2012) Two-phase growth of high topography in eastern Tibet during the Cenozoic. Nat Geosci 5(9):640-645. doi:10.1038/ngeo1538

Wang E, Meng K, Su Z, Meng Q, Chu JJ, Chen Z, Wang G, Shi X, Liang $X$ (2014) Block rotation: tectonic response of the Sichuan basin to the southeastward growth of the Tibetan Plateau along the Xianshuihe-Xiaojiang fault. Tectonics 33(5):686-718

Xu ZQ, Ji SC, Li HB, Hou LW, Fu XF, Cai ZH (2008) Uplift of the LMS range and the Wenchuan earthquake. Episodes 31:291-301

Xu X, Yeats RS, Yu G (2010) Five short historical earthquake surface ruptures near the Silk Road, Gansu Province, China. Bull Seismol Soc Am 100(2):541-561 
Xu X, Ding Z, Shi D, Li X (2013) Receiver function analysis of crustal structure beneath the eastern Tibetan Plateau. J Asian Earth Sci 73:121-127

Xu X, Keller GR, Gao R, Guo X, Zhu X (2015) Uplift of the Longmen Shan area in the eastern Tibetan Plateau: an integrated geophysical and geodynamic analysis. Int Geol Rev (ahead-ofprint): $1-18$

Yang Y, Ritzwoller MH, Zheng Y, Shen W, Levshin AL, Xie Z (2012) A synoptic view of the distribution and connectivity of the mid-crustal low velocity zone beneath Tibet. J Geophys Res 117(B4):B04303

Yin A, Harrison TM (2000) Geologic evolution of the HimalayanTibetan orogen. Annu Rev Earth Planet Sci 28(1):211-280
Yuan D-Y, Ge W-P, Chen Z-W, Li C-Y, Wang Z-C, Zhang H-P, Zhang P-Z, Zheng D-W, Zheng W-J, Craddock WH, Dayem KE, Duvall AR, Hough BG, Lease RO, Champagnac J-D, Burbank DW, Clark MK, Farley KA, Garzione CN, Kirby E, Molnar P, Roe GH (2013) The growth of northeastern Tibet and its relevance to large-scale continental geodynamics: a review of recent studies. Tectonics 32(5):1358-1370

Zhang PZ (2013) A review on active tectonics and deep crustal processes of the Western Sichuan region, eastern margin of the Tibetan Plateau. Tectonophysics 584:7-22

Zhang Z, Deng Y, Teng J, Wang C, Gao R, Chen Y, Fan W (2011) An overview of the crustal structure of the Tibetan Plateau after 35 years of deep seismic soundings. J Asian Earth Sci 40(4):977-989 